\title{
THE BLESSED VIRGIN MARY AS OUR MOTHER. THE LUCAN MARIAN PERSPECTIVE
}

\section{INTRODUCTION}

The importance of the person of the Blessed Virgin Mary has always been central in the salvation History after the position of her Son our Lord Jesus Christ. Many Christians have found her spiritual help in their cause of developing their faith. In fact she has been referred with noble titles that inspire devotion among Christians of different ages. Unfortunately Mariological dissension down the Christian Tradition has almost disfigured her prominent position in the Mission and ministry of Jesus. Many people have not been able to learn from Mary her heroic virtues while others have missed the chance of learning from her lessons on how to follow Christ carefully.

The aim of this work is to deepen the understanding of Mary as our faithful companion as found in the New Testament by Luke. We shall divide her companionship in two sections the first one as our mother and the second one as our big sister. Through this article the reader will get a clear picture of the relevance of Mary's mission today and through her maternal and close mediation she will lead us to her Son. Our response to her teaching will depend greatly on our knowledge of her special ministry in the history of salvation. This understanding includes our understanding of who she is to Christ and secondly who she is to us. For who she is to us is the concern of our article briefly 
examining who she was to Christ and applying it to us her spiritual sons and daughters. Mary is one with the human race, for she is totally a human person like any other, she is not a god, and she is not part of the Trinity. But she is a creature one of those to be redeemed by the redemptive works of Christ, she journeys with us praying with and for us. Bigotto writes that, "She is a woman rich in those human qualities searched for in all societies because they are part of the Kernel of what is human." Human society looks for a person who can be faithful, trustworthy and actively engaged in making human life better. This underlines the necessity of the life and ministry of the Blessed Mother to us today in spite of our denomination or religious affiliations. In this first scope we will examine the events of annunciation, visitation and Nativity as presented by St Luke. In these events she teaches us how to be human and how to do God's work without losing touch with fellow human beings. Hence her role as a mother is well demonstrated. There is no better way of being companions of God's word than following the model of the Blessed Virgin Mary.

The paper carefully follows the figure of Mary from the Gospel of Luke and Acts of the Apostles. The Gospel is Christocentric for it gives an account of the Good News of our Lord Jesus Christ but Mary is at the center of the Good News linking man to God and God to man in her womb and in her life. In turn the Church should follow the model of Mary and labour more to be a trustworthy companion to all those who are in sickness, loneliness, hunger among other needs.

\section{ANNUNCIATION OF THE BIRTH OF JESUS (LK 1:26-38)}

The Gospel of St Luke is arguably a Marian Gospel, in the sense that it highlights in more details the events that puts Mary at the center of the salvation history. This event begins with the infancy narratives

${ }^{1}$ G. Bigotto, Mary the mother of Jesus; Exegesis and Spirituality, Nairobi 2000, p. 218. 
of Jesus. In these events the coming of the Saviour as was prophesied in the Old Testament ${ }^{2}$ is made manifest through the message of the archangel Gabriel. ${ }^{3} \mathrm{He}$ announces to her a divine message which was long awaited by Israel from of old. The message had a dramatic turn of events: first of all, to Mary, and secondly to the entire humanity in reference to their salvation. The message of Gabriel to Mary required her to make a choice of accompanying the Word in becoming flesh in accordance with God's salvific plan for humanity in her own womb. Through the message of the birth of Jesus Mary was invited by God to accompany man in receiving this gift of salvation. This is a new dawn to man for in it an extra ordinary experience of God is ushered in where Mary's response to God's invitation was central in the redemption of man.

In the mystery of Incarnation ${ }^{4}$ Mary positively responded to God and she was to remain actively engaged in the upbringing of the fruit of her womb. This event of annunciation to Mary did put her at the core of Man's salvation. Luke mentions Mary as the one who receives the honour from God of granting him human nature through the power of the Holy Spirit. In the encounter with the arch-angel the Blessed Virgin Mary is presented as a virgin betrothed to Joseph. Our blessed mother gave birth without losing her virginity and after

2 The Old Testament prophets had fore told the coming of the Messiah as the liberator of the people of Israel. Cf. Is. 7:14, Jer. 31:31, Is. 61:1-2, Dn. 9:24-27, Zech. 12:10, Mal. 4:5-6 Hos 11:1, among other passages in the Old Testament. This event of the Annunciation is a fulfillment of the Old Testament.

3 The Arch Angel Gabriel is known as the messenger of Good News in the Bible. In the Old Testament he appeared to prophet Daniel (Dn 8:15-26, 9:21-27) and in the New Testament he is a key person in bringing the Good News to Zechariah, Elizabeth, Mary and Joseph (Lk 1:11-18, 1:19-25, and Lk1:26-38).

4 Incarnation as a mystery is to be understood here to be the climax of God's self-gift to man whereby God's Word receives the human nature from the Blessed Virgin Mary. Incarnation as a mystery reveals God and yet makes him hidden C/f Paul Helm, "The Mystery of the Incarnation, great is the Mystery of Godliness" The Southern Baptist Journal of Theology, Vol 19, No.1 (2015), p. 26. 
birth she remained a virgin throughout her life. ${ }^{5}$ Mary was a virgin before $^{6}$ to protect her integrity and bear testimony that her child is not a biological son of Joseph or any other man but of God. Thus she is close to God than any other being has ever or ever will be to God. No wonder she asks the Angel how it will happen since she knew no man.

The Angel made it clear that it shall be God's work through the Holy Spirit. Mary and the Holy Spirit are thus close companions in effecting the Incarnation. This explains to us that Mary is in a close relationship with God. She conceived with the divine help and thus her motherhood is divine. "Jesus is God's Son conceived through the coming of the Holy Spirit." "God requested Mary to give place in her life to His begotten Son by becoming his mother. In other words this pericope puts Mary at the center between God and man. Mary the Blessed Mother thus enters into the divine plan of Gods salvific works. She responded positively to God's invitation. Mary obeyed God first before she conceived Him in her womb. This shows us that to be companions of God in his redemptive work begins with obeying God by listening and doing God's will. Through Incarnation Mary accepted to accompany Jesus in her womb and even on his earthly life as he seeks to reach out to man. Her response was determinant on the pace at which the fulfillment of God's promises would be achieved.

In the words of Bishop Fulton Sheen, "a creature was asked by the creator if she would freely cooperate with God's plan to take

5 A. Buono, The greatest Marian Titles, Their meaning and usage, New York 2008, p. 89.

6 Mary conceived her son as a virgin miraculously without any man for with God nothing is impossible $\mathrm{C} / \mathrm{f} \mathrm{Lk}$ 1:37. This virginal birth has a theological relevance of safeguarding the Divinity of Christ C/f Van A. Harvey, A Handbook of Theological Terms, Their Meaning and Background Exposed in over 300 articles, (New York: The Macmillan Company 1966), 247-248. Also great teachers of faith spoke of Mary as having remained a virgin throughout her life some of these includes, Athanasius (Alexandria, 293 - 373), Epiphanius (Palestine, 315? - 403), Jerome (Stridon, present day Slovenia, 345? - 419), Augustine (Numidia, now Algeria, 354 - 430) Cyril (Alexandria, 376 - 444) and others.

7 R.E. Brown, Mary in the New Testament, New York 1978, p. 125. 
humanity out of the mire and to let him be ravished totally by God." Her companionship becomes her collaborative work in the work of salvation. This is amazing how God was bending down asking Mary to accompany Him in a very unique way as He seeks to elevate man in his rightful place which he had lost through $\sin ^{9}{ }^{9}$ The blessed mother by her acceptance to be the mother of Jesus became "the source and giver of life." 10 This is not for Mary's benefit not for Gods benefit but for man's salvation in which Mary is part of the humanity to be redeemed. The blessed Virgin had her plans of being a life companion to Joseph through the natural law of marriage that is being a life partner in matrimony. But now she has to make a choice for the whole man in response to God's will. No wonder she asks the Angel how this shall be for she understood the natural way of conception while for her case she was still a virgin. ${ }^{11}$ Her calling was a special ministry to Jesus as he progresses in human growth and development.

Motherhood offers a very vital role in the wellbeing of any organism. Through such a role Mary was a necessary companion to baby Jesus. On one hand the yes of Mary in the annunciation was a yes to accompanying Jesus in her own right freely so that He can acquire human nature from her womb. On the other hand she was giving company to humanity to approach God in their humanity. Through her yes she simply said to God I will be your mother bringing you to your creation and bringing creation to you. She is therefore a bridge between man and God. The concept of motherhood incorporates

8 F. Sheen, The World's First Love, San Francisco 2010, p. 33.

${ }_{9}$ Cf. Gen 3:15.

10 A. Liguori, The Glories of Mary, Saint Louis 1931, 76.

${ }^{11}$ Didymus proclaimed Mary and addressed her as the perpetual virgin (Mary was a virgin before birth, during and after the delivery of her first born). Cf. J. Quasten, Patrology, Vol. III - The Golden Age of Greek Patristics Literature from the Council of Nicaea to the Council of Chalcedon, Notre Dame, p. 99. St Augustine also in his sermon 51, 18 noted that "a virgin she conceived, a virgin she gave birth, a virgin she remained" teaching on the perpetual virginity of Mary. J. Quasten, Patrology, Vol IV - The Golden Age of Latin Patristic Literature from the Council of Nicaea to the Council of Chalcedon, Turin 1986, p. 432. 
in itself the rationale of faithful accompaniment in all stages of human development. Through her motherhood as espoused in the annunciation she was invited to conceive, bore, nourish and up bring Jesus. These aspects calls for a life time commitment. This explains why motherhood is not a nine month or a one day engagement but a life time commitment. Mary aware of her calling said God's will be done and she remained faithful in her noble task of bringing God to man and man to God.

Thus Mary accepting to be his mother gave him the best accompaniment ever worth the name because of her faithfulness in God's Word. She thus accepted a role which is so noble and well understood in all societies. Having been a companion to our Lord her accompaniment is now extended to all those who have become adopted sons and daughters of her son through baptism. ${ }^{12}$ Her acceptance of Gods will in her life accords her a moral obligation to be a mother and accompany all those who through baptism will become God's children through the sacrament of baptism. Accompanying them through her mediatorial role, ${ }^{13}$ and awaiting them in Heaven where she was assumed after her death. ${ }^{14}$

Through the message of angel Gabriel, Mary becomes a prominent figure out of God's grace in God's salvific plan for man through the coming of the long awaited promise, that is, the Messiah. Her motherhood is linked to the mission and the ministry of Jesus the

12 Baptism makes us adopted sons of God and incorporates us into his mystical body the Church. Cf. Catechism of the Catholic Church, no. 1267. His biological Mother becomes the Mother of all those who have been purified through the sacrament of baptism.

13 Mary has been understood to have a mediatorial role in the Church following her active presence and participation at the wedding in Cana of Galilee (Jn 2:2-11) from this pericope, "Mary is Christ's cooperator in the performance of the miracle she offers us in this account a full-fledged example of her intercession with her son." J. Bastero, Mary mother of the Redeemer, Dublin 2011, p. 144.

14 Pope Pius XII, in the Munificentissimus Deus, of 1950 declared the dogma of the assumption of the Blessed Virgin Mary. C/f Vatican.va>va>pius-xii > documents accessed on 16/12/2018 
saviour of humanity for she is the one who bore him and nourished him in all ways like any other mother would do to her child. But to accomplish this noble and divine task Luke tells us that she is "full of Grace" $" 15$ to enable her to accomplish her role effectively as she was pre-destined to become the Savior's mother. Luke doesn't forget to show the uniqueness of the motherhood of the Blessed Virgin Mary for there was no male involved. Even if the role of naming a child was a prerogative of the father the angel granted this role to Mary to name the child Jesus. ${ }^{16}$ This shows that the child born of Mary biologically belongs to her alone and asserts an upper hand of the Divine in her motherhood. Thus, the Holy Spirit is the spouse of the Blessed Virgin and she is the mother of the only God's begotten son. "Mary gave a conscious free "yes" to the human conception of the son of God."17

By her unique perfect character shown through her response to God she became an example to all people in their encounter with God. ${ }^{18}$ The angel told her that she would conceive and bear a son who will fulfill the messianic prophecies. In the annunciation as a theophany ${ }^{19}$ God visited Mary and entered in her heart and womb through the Holy Spirit for with God nothing is impossible. ${ }^{20}$ Mary became God's dwelling place, a place of encounter between man and God for God made his residence in her. Through the annunciation Mary receives her vocation of being the mother of God's son out of her

${ }_{15}$ Mary was prepared by God to be the Mother of her Son. He gave her the fullness of grace to enable her carry her task well. Cf. Lk 1:28.

16 Cf. Lk 1:31

17 J. Bastero, op. cit., p. 112.

18 Paul VI, Apostolic Exhortation, Marialis Cultus, no 33.

19 Theophany is God's self-Revelation and manifestation to Man. It results in vindication and right thinking among the people of God while his enemies are left confused and ashamed. See more on Tremper Longmann III, and Peter Enns (eds), Dictionary of the Old Testament, Wisdom Poetry and Writings A Compendium of Contemporary Biblical Scholarship, Downers Grove 2008, 817-820.

${ }^{20} \mathrm{Cf}$. Lc 1:37 With God nothing is impossible for Elizabeth though past the child bearing age has conceived. God works sometimes contrary to human wisdom for he is not limited as we are. 
faith in God she becomes God's companion and in turn accompanies all those who are God's Children.

Pittenger explains that for Mary to receive such an invitation she must have been a woman of faith: "There is no reason to doubt that from the time of her conception of Jesus, Mary was a person of faith."'21 Her role of accompanying the son of God was based on her faith in God and in his promises to humanity. We also look upon her as our companion for being a woman of faith she will help us deepen our faith in God. This will be translated into us being saved since faith is necessary for salvation. ${ }^{22}$ Last but not the least we can see Mary being a model of faithful accompaniment in all spheres of human and spiritual aspects. An accompaniment greatly desired in our families and in the entire society may she then accompany us until we reach God's abode. For when she said yes to God and to humanity she never looked back even in her sorrowful moments. She remained faithful to the responsibility that her yes implied in the earthly life of Jesus. Her yes we can say is a yes that has endured down the ages. The same yes made to God and to fellow men faithfully expressed in word and deed is a responsibility of every believer and Mary moves in company with us to help us accomplish it. It is also a challenge to us that we are to conceive God in our mind and heart so as imbued with the Gospel message we may give birth to Christ through our words and deeds. May she thus guide us to receive the Word in docility and joy and be living witnesses to the Spirit who overshadowed her on the annunciation.

\section{VISIT TO ELIZABETH (LK 1:39-45)}

When Mary visited Elizabeth various aspects of her role in the company of God and man are made explicit. Her greetings and conversation with Elizabeth exhibited what her vocation entailed. Mary obeyed the Word of God during the annunciation and now here

\footnotetext{
${ }^{21}$ N. Pitenger, Our Lady the Mother of Jesus, London 1996, p. 28.

22 Cf. Catechism of the Catholic Church, no. 1816.
} 
she becomes a model of faith and charity. ${ }^{23}$ Elizabeth recognized Mary as the mother of her Lord. In this, Elizabeth guided by the Holy Spirit acknowledged Jesus who was in the womb of Mary to be her Lord and recognized the divine maternity that was on the shoulders of the Blessed Virgin Mary. In other words she recognized the fact that Mary brought to her, her Lord in her own house. Mary's motherhood is charged with a responsibility of taking Jesus to those in need of Him. Mary in her body and Spirit accompany Jesus as he seeks to reach out to our families and lives. In fact, Elizabeth acknowledged that Mary is a blessed woman for being chosen by God to be His mother ${ }^{24}$ is a gratuitous gift. Her motherhood is special on account of the status of the one she is hosting in her womb. Through this visit Elizabeth makes us aware that Mary is truly a believer "happy is she who believed that there would be a fulfillment of the things spoken to her by the Lord."25 She is blessed because of believing in God's word spoken to her; she receives her vocation in faith trusting that what the angel told her, God would accomplish it.

Today we look for her to teach us on how to believe in God's Word as she did. So for Elizabeth Mary is in total commitment to God and she totally submits herself to God as she says, "May it be done to me according to your Word." ${ }^{26}$ Elizabeth would want us to know that the source of Mary's blessedness and joy is because she is a firm believer in God's promises. To be chosen by God to accompany him in visiting his people requires faith in Him and total surrender in his promises. Her joy emanates from her obedience to God. Thus Mary is a teacher to us in faithful obedience to our Lord. We need her to accompany us in responding faithfully to God's calling and in turn take Jesus to our relatives, friends and in deed to the entire humanity. Her motherhood doesn't only bring joy to her but to all those whom she meets and also on those who welcomes her or in other words those who are open to

\footnotetext{
${ }^{23}$ Catechism of the Catholic Church, no.967.

${ }^{24}$ Cf. Lk 1:42.

${ }^{25}$ Cf. Lk 1:45.

26 Cf. Lk 1:38.
} 
the richness of the mystery of Incarnation. This is why the child of Elizabeth leapt with joy after Mary's greeting to Elizabeth. Hence, "For Mary herself the coming of the one who would be her Lord was the culmination and fulfillment of the promises God made to Israel." ${ }^{\text {27 }}$ This is the point in her conversation with Elizabeth.

It's an encounter that fulfills the hope and the longing of all the Israelites. Mary taking Jesus to Elizabeth she participated in rejuvenating the heart of Elizabeth and assuring her that God is faithful to his promises. She helps Jesus in her womb to reach out to the poor ones of the Lord who have all along hoped for God's mercy represented here by the person of Elizabeth. Mary walks with Jesus to the Zechariahs home to introduce him to the young and old. The Blessed Mother accompanied Jesus to the prophets here represented by John the Baptist to witness his arrival to fulfill their prophecies. She took Jesus who was in her womb to the old represented here by her cousin Elizabeth who have been waiting the fulfillment of God's promises. Mary in this passage takes both the young and the old of our time to Jesus as well. Having been a relative to Elizabeth she wills to present her and her entire household to God.

This encounter is what Elizabeth filled with the Holy Spirit recognizes that Mary has taken her to God and even the child in her womb is full of Joy. Mary is thus a special Gift to humanity from God. This gift concerns taking us to God for God is with her in a motherchild relationship. She is thus through this visitation introducing Jesus to his mission of meeting man in his life situation. Through this same encounter she requests man to accept Jesus who comes to knock on their lives with the message of redemption and fulfillment. No other great companionship can equal this, God being brought to men and men being taken to God through the tender hands of our blessed Mother. She thus qualifies to be a bridge of Man to God and of God to man. This act of Mary has been interpreted to be a gesture of charity. This being the case then we infer that Mary's companionship to Jesus shows the magnitude of God's love to man. Mary's love to God and

27 J.D. Chrichton, Our Lady in the Liturgy, Dublin 1997, p. 10. 
man is also made manifest for in this journey she moves for the love of God and neighbor. ${ }^{28}$ On herself she is charitable to Elizabeth who is pregnant and elderly.

Mary stayed with Elizabeth for three months taking care of her during her pregnancy. Mary learnt of her pregnancy from the Angel and she felt duty bound to go and offer her company at such an hour of need. Mary's company to Elizabeth was providential at such an hour of her need. Hence her action is of genuine concern to the needy down to our ages we look forward for her continuous presence in our lives. In turn she exhorts men to demonstrate total love to God by accepting the one who is in her womb. Lastly Mary is offering a lesson to us to be charitable to our needy brothers and sisters. Mary's presence in the house of Zechariah and Elizabeth calls to be present in the lives of other people being one with them in whatever they go through. Today more than ever before, our society is in dire need for another Mary who will go in haste to the elderly, terminally ill, prisoners, marginalized and all those who are suffering in one way or another and accompany them in their hour of need. However, even as we arise to go to meet such people Mary demonstrates to us that we need to carry Jesus. On our own we may not quench their inner hunger and thirst but Christ in us will go down to the depth of their longing. We have an obligation to take Jesus to others in their life situations following this example of Mary to Elizabeth.

\section{NATIVITY (LK 2:4-20)}

The birth of Jesus opens a new chapter in the story of man in his relationship with God towards his redemption. It concerns the purpose of the Bible, the climax of salvation and through it we come to the climax of revelation. The letter to the Hebrews notes that Jesus "is the reflection of God's Glory and bears the impression of God's own being." 29 The person who is God's true image is born by the

28 Cf. Mat 22:35-40 and Mk 12:28-34

29 Cf. Heb 1:3. 
Blessed Virgin Mary in Bethlehem at a given time in History. After she conceived Jesus on the annunciation Mary now gives birth after housing him in her womb for nine months. The close proximity of Jesus and Mary is a model of Christian calling. Mary conceived the Word and bore the Word in body and in her life. For Luke Jesus was born in Bethlehem a town linked to David so as to link her child to the David's lineage as it was prophesied from the Old Testament that a saviour would be born from David's line. Thus Mary brought Jesus in a human body in the history of Israel. "Filled with the Holy Spirit she makes the Word visible in the humility of his flesh. It is to the poor and the first representatives of the gentiles that she makes him known." ${ }^{30}$ Today we look upon her to bring Jesus in our life situations.

In Luke's story of Nativity there are Angels who point to the divine presence accompanying their master who is now resting as a human baby on the arms of Mary his mother. Their presence emphasizes the miraculous birth or in other words the uniqueness of the one born. This in turn calls our attention to her who was found worth for such an extraordinary event. In other words we can see God's messengers accompanying him to his people represented here by the Virgin Mary and Joseph. Mary is thus a key witness that God comes to meet man. Mary keeps company to the infant Jesus orienting him towards being fully human. She is thus tasked with the care of the Son of the Most High God. She is expected by the Heavenly battalion to offer herself totally in the upbringing of the child she bore. The task on her shoulders is enormous and involves walking with him every day as he grows to assume his public ministry. As she accompanies him from nativity to the cross even though she is her biological mother she needs to be open to learn from Him. The company she gives to him is not to be interpreted to mean that he was lacking for He was God. ${ }^{31}$ And he lacked nothing though as man he was to be nurtured like any other human child. This why as we propose that we need to accompany him we are to accompany him with our eyes, mind and

${ }^{30}$ Catechism of the Catholic Church, No.724 also cf. Lk 1:15-19, Mt 2:11

${ }^{31}$ Cf. Jn 1:1ff. 
heart open so that He teaches us what to be human means and what is expected of us in our daily life as we look forward to our redemption.

Mary becomes necessary to us having given birth to Jesus she has what it takes to teach us how to accompany him as he works for our salvation. The presence of the shepherds during nativity is also very important. It is full of meaning and Mary brings Jesus who is the prophesied shepherd from the prophecies of the Old Testament. He comes to be the chief Shepherd and he is welcomed by the literal shepherds who here represent the poor ones who have no one to take care of them. Mary accompanies Jesus to the shepherds as one with them and as their mother instilling hope through her child. Mary accompanies Jesus on his way to the world in the human form. He will later in the Gospels be referred to as the Good Shepherd. ${ }^{32}$ The flock of Christ now looks upon Mary to bring her son who is their shepherd so as to fulfill their dreams. This is the task of Mary that was entrusted to her and she carried it out faithfully.

By presenting the shepherds the author wants the poor ones included in the Marian responsibility as she sang in her magnificat he uplifts the lowly ${ }^{33}$. In other words Mary brings Jesus to the shepherds to uplift them. The shepherds on the other hand come to receive the messiah as one with them. Hence the arrival of the Messiah through the nativity of the Blessed Virgin Mary is the arrival of the liberator of humanity especially the downtrodden..$^{34}$ Their presence at the birth of Jesus signifies the action and communication of God by respecting his transcendence. ${ }^{35}$ The purpose of Jesus coming has been presented in the Gospel of St Luke to show that he came to save man from oppression of all that which demeans his dignity. Mary thus stands

${ }^{32}$ Cf. Ez 34:1-24, Is 40:11, Mic 5:4. Ps 23 sings of a good shepherd who is understood in the New Testament perspectives to be Jesus Christ. In the New Testament Christ is understood to be the good shepherd prophesied and in fact he refers to himself as a good shepherd Cf. Jn 10:11, Mt 25:31-46, and Heb 13:20

${ }_{33}$ Cf. Lk 1:52.

34 Cf. Lk 4:16-18

${ }_{35}$ R. Laurentin, Mary in Faith and Life in the New Age of the Church, Ndola 1983, p. 93. 
with the poor at the nativity presenting to them their liberator and on the other hand she stands with the poor ones to receive Him. Mary thus plays a double role as the one who accompanies Jesus to his friends the poor ones of the Lord and as the one who together with the poor ones readily welcomes him in the human history with a joyful expectation of their redemption. This is why the event of Nativity is a joyful occasion and the Church too rejoices in her maternity. As Crichton writes, "It is the feast of the mother who brought forth the redeemer of the world. As such, she is seen to be more closely associated with him than any other human being and her relationship with him is the root and source of all her dignity, honor and grace." 36 The close association between Mary and Jesus becomes a model of human and divine companionship for the salvation of man and the glory of God.

More than the physical giving birth Mary was there at the manger to welcome Jesus to this world in a new way. We call it a new way in that Jesus though God had not come in the world prior to his birth in a human body. As a human baby, Jesus was warmly received in her arms and she took care of him in all the facets of human and spiritual dimensions. The nativity is always new inviting us to look on Mary as she gives birth to our saviour and as she urges us on to receive her son in our lives in faith. She brings Jesus to each one of us so that our life may be made perfect. This perfection implies entering into communion with God in a unique way as he grows in his human form as we watch him drawing from him his divine power and benevolence. Hence Mary the blessed mother invites us to grow with her son as she brings him up. In turn she opens her arms to welcome us in her family to up bring us in faith so as to acknowledge the Lordship of her son.

\section{CONCLUSION}

To faithfully receive Mary as our companion in life we must brace ourselves for the task ahead, a task of embracing our Christian calling

${ }^{36}$ Crichton, Our Lady in the Liturgy, p. 27. 
faithfully without losing sight of the promise. This is What the Blessed mother excelled in and is what her companionship to us endeavors to achieve. The challenges in this calling are enormous and they pose questions which might have no answers. However, with Mary as our blessed Mother on our side and having trekked the same journey in a unique way and faithfully succeeded she will guide us to the end. Hence taking her as our mother and model we will finish the race faithfully. This is why this article has demonstrated how she can be a sure source of inspiration and hope to the men and women today as their mother and companion. It is also a modest provocation to the modern man to dare to give himself totally to God's work in trying to grow in love of God and neighbours in a more pragmatic way in all stages of human development and growth as Mary did in the life of Jesus. This is also what she does in the lives of all those who look upon her as their mother and model. The Blessed Virgin Mary was engaged in throughout her earthly life in this noble ministry and even today she is proactive in mothering and nurturing many more children of God through her intercessory and mediatorial role. And even now she still participates in the history to make sure as a spiritual mother all her Children achieves eternal life which was promised by her Son and in which she herself has received from Him. This is why we have proposed her as a faithful companion as presented in the Lucan writings in the New Testament. The next part will examine three passages from the Luke.

\footnotetext{
Abstract

The person of the Blessed Virgin Mary among Christians has been throughout Christian tradition a source of inspiration as far as the Christian faith is concerned. Many papal Encyclicals, Apostolic exhortations, conciliar and post conciliar documents have all made reference to our blessed mother due to her close proximity to her son our Lord Jesus Christ. She is thus not a foreigner to the people of faith. The modern man today looks forward for a person who is both faithful and trustworthy to accompany him or her in the earthly life and offer an assurance of everlasting joy. Examining the role of Mary in the writings of St Luke in the New
} 
Testament we see Mary as the one who fits in this desire of the modern man. Her role as a mother in the Luke's view is very central in understanding the notion of companionship. However many people today do not understand Mary to be a faithful companion, perhaps this is due to the misunderstanding of Mary's position in the Salvation History. Moreover the Sacred Scriptures from the infancy narratives to the neophyte church in Acts of the Apostles Mary makes a journey of faith with Jesus and his disciples. Thus in this article we examine briefly the companionship of the blessed Mary to the Word of God as we invoke her companionship to our Christians today on their pilgrimage to the Promised Land.

Key Words: Mary, Annunciation, Visitation, Nativity

\section{Streszczenie \\ Tytuł po polsku proszę podać \#\#\#\#}

Najświętsza Maryja Panna jest źródłem inspiracji, jeśli chodzi o wiarę chrześcijańską. Wiele encyklik papieskich, adhortacji apostolskich, dokumentów soborowych i posoborowych odnosiło się do Matki Bożej z powodu Jej Syna, naszego Pana Jezusa Chrystusa. Współczesny człowiek poszukuje osoby, która jest zarówno wierna, jak i godna zaufania, aby towarzyszyć mu w ziemskim życiu i zapewnić wieczną radość. Badając rolę Maryi w pismach św. Łukasza, widzimy Maryję jako tę, która spełnia to pragnienie współczesnego człowieka. Jej rola jako matki w poglądach Łukasza jest bardzo ważna dla zrozumienia pojęcia towarzystwa. Jednak dzisiaj wielu ludzi nie rozumie, że Maryja jest wierną towarzyszką, co być może wynika z niezrozumienia pozycji Maryi w historii zbawienia.

Słowa kluczowe: Maryja, Zwiastowanie, Nawiedzenie, Narodzenia

\section{Bibliography}

Bastero, Juan, Mary mother of the Redeemer, (Dublin: Four Court Press, 2011)

Brown E. Raymond, et al eds., Mary in the New Testament, New York: Paulist Press, 1978

Sheen, Fulton, The World's First Love, San Francisco: Ignatius Press, 2010.

Buono, Anthony, The greatest Marian Titles, Their Meaning and Usage, New York:

St Pauls Publishers, 2008

Chrichton, J.D., Our Lady in the Liturgy, Dublin: The Columba Press, 1997, 
Giovanni, Bigotto, Mary the Mother of Jesus; Exegesis and Spirituality, Nairobi: Paulines Publications Africa, 2000.

Harvey, A. Van, A Handbook of Theological Terms, Their Meaning and Background Exposed in over 300 articles, New York: The Macmillan Company 1966.

Helm, Paul "The Mystery of the Incarnation, Great is the Mystery of Godliness" The Southern Baptist Journal of Theology, Vol 19, No.1 (2015), 25-37

Interdicasterial commission, Catechism of the Catholic Church Revised edition, Nairobi: Paulines Publications Africa, 2011

Laurentin, Rene, Mary in Faith and Life in the New Age of the Church, Ndola: Franciscan mission press, 1983.

Liguori, Alphonse, The Glories of Mary, Saint Louis: Redemptoris Fathers, 1931

Paul VI, Apostolic Exhortation, Marialis Cultus, Nairobi: Paulines Publications Africa, 1974,

Pitenger, Norman, Our Lady the Mother of Jesus, London: SCM Press Ltd, 1996, Pope Pius XII, in the Munificentissimus Deus, of 1950 Vatican.va>va>pius-xii> documents accessed on 16/12/2018

Quasten, Johannes, Patrology, vol. IV - The Golden Age of Latin Patristic Literature from the Council of Nicaea to the Council of Chalcedon, Turin: Marietti, 1986, Quasten, Johannes, Patrology, vol. III - The Golden Age of Greek Patristics Literature from the Council of Nicaea to the Council of Chalcedon, Notre Dame: Ave Maria Press

Tremper Longmann III, and Peter Enns (eds) Dictionary of the Old Testament, Wisdom Poetry and Writings A Compendium of Contemporary Biblical Scholarship, Downers Grove, Illinois: IVP Academic, 2008.

Author: Zachary Ndegwa Kabatha is a priest of the Catholic Archdiocese of Nyeri (Kenya), born on $21^{\text {st }}$ August 1980, ordained priest on $28^{\text {th }}$ of July 2012, obtained licentiate in dogmatic theology from the Catholic University of Eastern Africa (on Nov 17, 2017). Currently a PHD student in dogmatic theology at Cardinal Stefan University in Warsaw (UKSW). Mail: zakkabatha@gmail.com 